\title{
Distribution of Tax Morale: Evidence from Behavioral Experiments
}

\author{
Jian Cao and Ya Zhou* \\ School of Systems Science, Beijing Normal University, Beijing, China \\ ${ }^{*}$ Corresponding author
}

\begin{abstract}
As a personal factor of taxpayers, tax morale plays an important role in tax compliance experiments. The difference of taxpayers' moral consciousness is also one of the important reasons for the difference of tax compliance game experiments. In this paper, the taxpayer's tax morale can be represented to some extent by the initial declared income of the taxpayer. Many experts and scholars also mentioned that the initial selection distribution should be paid attention to in the game experiment. In addition, we discussed the game experimental data of multi-group tax compliance, analyzed the distribution and difference of the initial declared income of taxpayers, as well as the behavior of taxpayer in the subsequent game experiments. The study found that the initial declared income was not normally distributed. Under the same premise of tax payment mechanism, there is no significant difference in the distribution of taxpayers' tax morale in different experimental experiments. From the perspective of tax morale, both the different risk preference and gender of taxpayers have a significant correlation with tax morale. Therefore, when formulating tax policy, the government should take into account the behavior of different tax morale people. These results are based on a lot of data, and the relevant rules can provide reference for other related experiments.
\end{abstract}

Keywords-tax compliance; tax morale; risk preference; behavioral game

\section{INTRODUCTION}

Tax compliance issue is a complex economic behavior problem, and the survey needs the use of various methods and rich source of data. Ronald G (2009) has proposed that one of the most difficult issues for governmental policymakers in developing and transformational economies is to encourage high level of tax compliance. In traditional tax compliance model of expected utility theory (e.g. classic A-S model), It has always been assumed that tax payment is the action which makes taxpayers maximize their own income under the premise of complete rationality. However, in our real life, with more and more empirical research, it is obvious that this theory is not applicable. Alm (1999) pointed out that, through the experience and empirical results, it was found that the A-S deterrent model could lead to more tax loss and lower tax compliance in some cases ${ }^{[1]}$. Myles and Naylor (2003) pointed out that the theoretical prediction results are not always the same as the actual situation ${ }^{[2]}$. Torgler (2010) found that most people pay more taxes than traditional models predict ${ }^{[3]}$. In many countries, there are low tax rates and penalties, but taxpayers have a high level of tax compliance. Therefore, the influence factors of tax compliance are not only limited to rational economic shock and awe variables, but also have the common function of other factors. Then, the emergence of prospect utility theory is from the perspective of behavioral economics, which further analyzes and elaborates the influencing factors of tax compliance issue.

So what are the factors that affect tax compliance? Friedland, Maital and Rutenberg (1976) believed that risk preference and tax compliance also had a strong correlation ${ }^{[4]}$. Grable (2000) believes that with the increasing of age and social experience, taxpayers' perception of taxation will also change, and young people will be more inclined to take risks than old people ${ }^{[5]}$. Nelson J A (2012) proposed that men and women have different ability of taking risks for uncertain situations. Because men are more likely to take risk as a challenge, they have a higher ability of taking risks than women ${ }^{[6]}$. Bonte W (2015) pointed out that "rule disrupters" may have common characteristics, such as age, gender, socioeconomic status and personal characteristics ${ }^{[7]}$.

Among all the influencing factors, the tax morale level of one's own and inner quality is a very important variable in the tax compliance experiment. Many researchers believed that each individual has an internal incentive to pay taxes -sometimes called "tax morale". Tax morale, as a very important personal factor of taxpayers, has a great influence on the difference of individual behavior decision in tax compliance experiment. Roth (2005) pointed that the taxpayer will be influenced by the social moral factors in the process of paying taxes according to law. Taxpayers are able to pay their own taxes, not only in their own interests, but also in social moral responsibility. Therefore, the higher level of taxpayers' morality is, the higher the tax compliance will be ${ }^{[8]}$. Bruno $\mathrm{s}$. Frey (2007) demonstrated that tax ethics is a key factor in determining tax behavior in the empirical study ${ }^{[9]}$. Brizi A (2015) puts forward that the tax morale of people determined the value direction of the whole society, while the direction of social value also affected the degree of expected tax compliance $^{[10]}$. Grundmann S (2017) proves that the tax morale of taxpayers will decrease with the decrease of their own income and the government tax level ${ }^{[11]}$.

For the taxpayer's tax morale measure method, the western scholars generally applicable is the world values survey (WVS) that is the judgment of the taxpayer for tax evasion as tax moral measure a variable. However, the taxpayers' own assessment of their own tax morality is very subjective, and the final evaluation result is not consistent with the objective facts. Huang Yang (2014) proposed that in the game experiment, the differences of the participants in the first-round decision should 
be paid attention to ${ }^{[12]}$. Therefore, based on the subjective shortcomings of the former scholars' assessment of tax morale, we proposed that: the taxpayer does not have any feedback of historical information in the initial experiment, nor does it have any influence on the experimental environment in the game experiment of behavioral economics. Therefore, in the case of the same initial conditions of other experiments, taxpayers' tax morale can be represented to some extent by their initial declared income.

\section{DATA BACKGROUND}

We conducted a lot of game experiments in these years, and strictly controlled the initial conditions and other external factors. We tried to ensure that there was no difference in any indicative language, and all participants had the same test parameters. The initial income is 1,000 yuan and the tax rate(t) is $40 \%$. The audit rate is $20 \%$ and the penalty rate(f) is $150 \%$.It means that the system only deducts the amount equal to $40 \%$ of the declared income as the amount of tax payment. If the participant was found that his declared income is lower than his real income, the participant will not only be taxed at $40 \%$ of his real income, but will also be fined $150 \%$ of his amount of tax evasion. In other words, none of these parameters changed in all rounds, and all the participants knew the information. The experimental procedure is as follows:

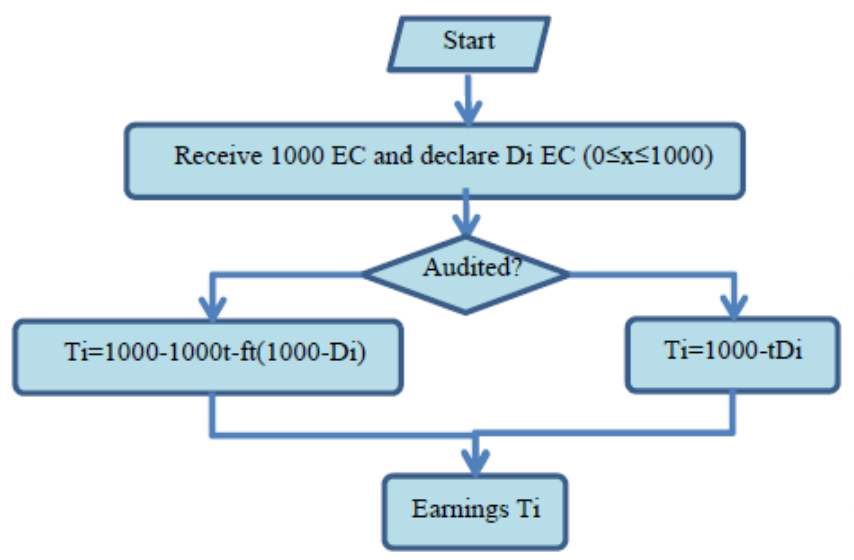

FIGURE I. THE EXPERIMENTAL PROCEDURE

And then in all game experiments, we selected two representative groups of experiments which have the most similar experimental environment, what's more, the two experiments were conducted at the same site for the counterparts. Finally, we based on the two different kinds of tax compliance mechanism, to explore the participants on the distribution of the tax morale at the begining of the game. The experimental data in this paper are derived from two groups of behavioral game experiments. In order to meet the randomness of the sample, the two experiments were conducted at Beijing Normal University(BNU) and Panjin Vocational and Technical College(PV\&TC). There are a total of 244 people participated in the experiments. Among them, 120(49.18\%) were male participants. In addition, 78(66.66\%) of participants in Beijing Normal University majored in natural science.
TABLE I. THE DISTRIBUTION OF THE TWO EXPERIMENTS OF SUBJECTS

\begin{tabular}{|c|c|c|c|c|c|c|}
\hline \multirow[b]{2}{*}{ Experiment } & \multirow[b]{2}{*}{ Place } & \multicolumn{2}{|c|}{ Gender } & \multicolumn{2}{|c|}{ Major } & \multirow[b]{2}{*}{ Total } \\
\hline & & Male & Female & $\begin{array}{l}\text { Natural } \\
\text { Science }\end{array}$ & $\begin{array}{c}\text { Social } \\
\text { Science }\end{array}$ & \\
\hline \multirow{2}{*}{$\begin{array}{l}\text { Local } \\
\text { information } \\
\text { group }\end{array}$} & BNU & 36 & 30 & 30 & 36 & 66 \\
\hline & $\begin{array}{c}\text { PV\&T } \\
\text { C }\end{array}$ & 17 & 43 & --- & --- & 60 \\
\hline \multirow{2}{*}{$\begin{array}{l}\text { Public } \\
\text { goods } \\
\text { return } \\
\text { group }\end{array}$} & $\mathrm{BNU}$ & 28 & 23 & 48 & 3 & 51 \\
\hline & $\begin{array}{c}\text { PV\&T } \\
\text { C }\end{array}$ & 39 & 28 & --- & ---- & 67 \\
\hline Total & & 120 & 124 & ---- & ---- & 244 \\
\hline
\end{tabular}

number of truthfully declared applicants, NAD is the total number of experiments), and the rate of tax declaration is $D C$ (DC is the declared income). $\overline{1000}$

During the implementation phase, 20 rounds of experiments were carried out for each experimental group, and participants were required to fill in their own reporting income. At the end of each round, the feedback is displayed on the computer screen. For example, the information provided in the local information group is the participant's own reporting of this round $\mathrm{Di}$ and earnings $\mathrm{Ti}$, and the average declared of the others in the same experimental group. And the participants in the public goods returned group, in addition to knowing that a part of their own taxes will be returned to themselves as public goods, the only feedback information they will get is their own reporting $\mathrm{Di}$ and earnings $\mathrm{Ti}$.

After 20 rounds of experiments, the participants were asked to fill in a questionnaire, which mainly involved the gender, major, risk preference and other identity characteristics. After completion, the system will randomly select 1 round from the 20 rounds of experiments and convert it to a certain percentage as the final experimental reward. The average pay is around 50 yuan, and the experiment is about 35 minutes. The z-tree experimental platform recorded the data of the experimental process, including the number of subjects, the selection of each round and the information of the income and identity characteristics.

\section{RESULTS}

The following four aspects are analyzed: the overall distribution characteristics, the distribution of tax ethics under different experimental designs and different identities, and the difference of behavior of different tax morale people in the whole game experiments. Next, we distribute it according to frequency, the experimental population is divided into five categories: 
TABLE II. GROUP DIVISION

\begin{tabular}{lll}
\hline The initial declared income (yuan) & Group & Frequency \\
\hline $0-99$ & Low tax morale & 36 \\
$100-499$ & Lower tax morale & 30 \\
$500-699$ & Middle tax morale & 33 \\
$700-899$ & Higher tax morale & 59 \\
$900-1000$ & High tax morale & 86 \\
\hline
\end{tabular}

Through the analysis of these four aspects, we found that:

A. The Overall Tax Morale Distribution is Characterized by a High Number of People with High Tax Morale, and a Low Number of Low Tax Morale

TABLE III. DESCRIPTIVE STATISTICS OF THE OVERALL INITIAL DECLARED INCOME

\begin{tabular}{llllllr}
\hline Mean & SE Mean & Midian & $\begin{array}{l}\text { Standard } \\
\text { Deviation }\end{array}$ & \multicolumn{2}{c}{ Minimum Maximum Sig. } \\
\hline 633.27 & 23.578 & 800.00 & 368.30 & 0 & 1000 & 0.000 \\
\hline
\end{tabular}

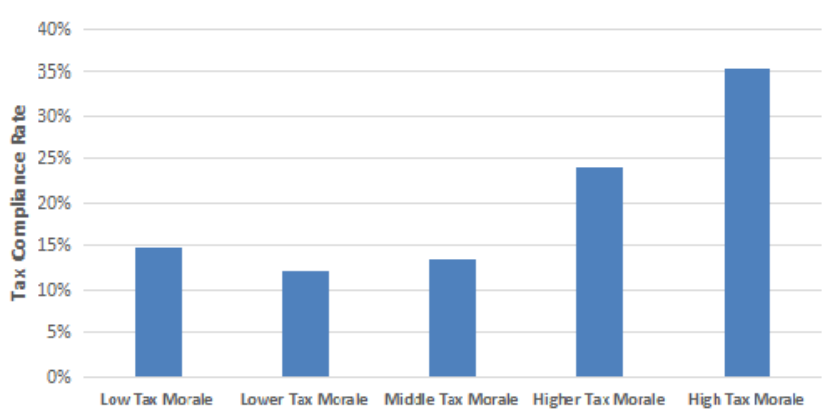

FIGURE II. THE OVERALL INITIAL DECLARED INCOME DISTRIBUTION

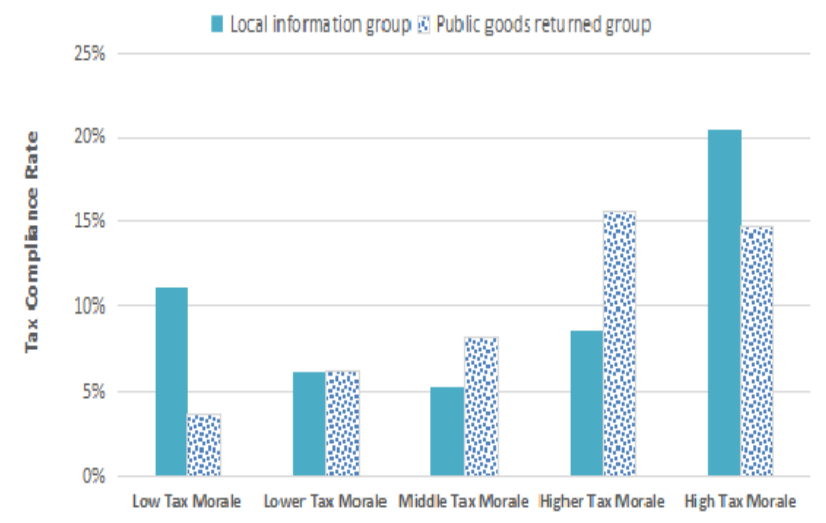

FIGURE III. THE PERCENTAGES OF THE TWO GROUPS IN THE DIFFERENT TAX MORALE GROUPS

The results in Table 3 showed that the mean of the initial declared income is 633.27 , the median is 800 , apart from the maximum and minimum, the skewness coefficient is greater than 0 , and the distribution showed a right partial distribution, which is relatively concentrated. It showed that most participants tend to declare the income closing to their real income. After the normal test, we found that the initial declared income sig. $=0.000$, so it didn't satisfy the normal distribution.

From figure 2, The overall tax morale distribution is characterized by a high number of people with high tax morale, and a low number of low tax morale. As it can be seen from the figure 3 , the high tax morale group had the highest number of participants, and then is the higher tax morale group, but the number of people which with lower tax morale and low tax morale group has significantly decreased. In the low tax morale group, the number of the participants which experiment is the local information group is significantly higher than that of the public goods returned group. However, in the high tax morale group, the number of the participants which experimental experiment is the public goods returned group is significantly higher than that of the local information group. Does the difference in the experiment of the experiment really affect the initial declared income? Next, we tested whether there were significant differences in the distribution of tax morale under the different experimental experiments. We found that:

\section{B. There is no Significant Difference in the Distribution of Tax Morale in Different Experimental Experiments}

TABLE IV. THE DISTRIBUTION OF TAX MORALE IN DIFFERENT EXPERIMENTAL EXPERIMENTS

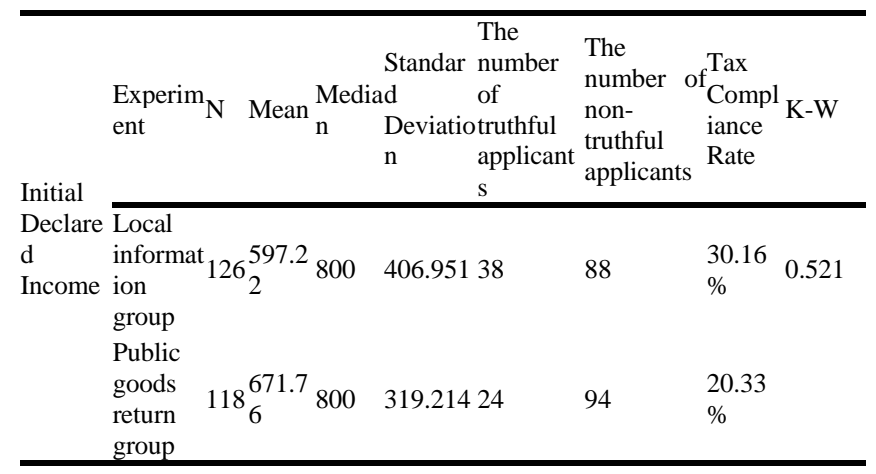

TABLE V. THE DISTRIBUTION OF TAX MORALE IN DIFFERENT EXPERIMENTAL PLACES

\begin{tabular}{|c|c|c|c|c|c|c|c|c|}
\hline \multirow{3}{*}{$\begin{array}{l}\text { Initial } \\
\text { Declared } \\
\text { Income }\end{array}$} & Place & N Mean & $\begin{array}{l}\text { Media } \\
\mathrm{n}\end{array}$ & $\begin{array}{l}\text { Standard } \\
\text { Deviatio } \\
\mathrm{n}\end{array}$ & $\begin{array}{l}\text { dhe } \\
\text { number } \\
\text { of } \\
\text { of truthful } \\
\text { applicants }\end{array}$ & $\begin{array}{l}\text { The } \\
\text { number } \\
\text { len- } \\
\text { struthful } \\
\text { sapplicants }\end{array}$ & 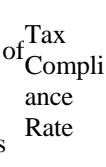 & $i_{K-W}$ \\
\hline & Beijing & $117 \begin{array}{l}759.6 \\
8\end{array}$ & 800 & 25.684 & 32 & 85 & $\begin{array}{l}27.35 \\
\%\end{array}$ & 0.000 \\
\hline & Panjin & $127{ }_{2}^{516.8}$ & 600 & 35.720 & 31 & 96 & $\begin{array}{l}24.41 \\
\%\end{array}$ & \\
\hline
\end{tabular}

From the Table 4, it can be found that the larger mean of the initial declared income is the public goods return group, which is 671.76. and the smaller mean of the initial declared income is the local information group, which is 597.22. We found that the mean of the tax morale of the public goods return group was slightly higher than that of the local information group, but the median of the two groups was the same, both of them were 800 . In addition, the tax compliance rate of local information group was higher than that of public 
goods return group. However, after the non-parametric test, the significance test of local information group and public goods return group was $\mathrm{P}=0.521(\mathrm{P}>0.05)$, indicating that there was no significant difference between the two groups. Therefore, there is no significant difference in the distribution of tax morale in different experimental experiments.

From the Table 5, the distribution of experimental groups in Beijing and Panjin is roughly the same, and there is no significant difference in the tax compliance rate. However, in terms of the overall two experiments, the average initial declared income of the students in Beijing Normal University is significantly higher than that of the students in Panjin Vocational and Technical College. It is found that the distribution of tax morale of two different students groups $(\mathrm{P}=0.000)$, which shows that there is a significant difference in the distribution of tax morality between the two students groups. And we guess that, on the one hand, it is the difference of the experimental results caused by the sample of students. On the other hand, it is also possible that the tax culture and tax morale between different regions are different. Therefore, further discussion is needed.

\section{The Risk Preference and Gender of Different Participants were Correlated with Tax Morale}

According to previous studies, there should be significant differences in tax morale among participants of different risk preferences in our experiments. and the similar identity information, such as gender and professional background, should also show a significant impact on the tax ethics of the participants. Therefore, we conducted the following test:

TABLE VI. THE DEGREE OF CORRELATION IN TAX MORALE BETWEEN THE RISK PREFERENCE AND GENDER

\begin{tabular}{|c|c|c|c|c|c|}
\hline \multirow[t]{2}{*}{ Statistics } & \multicolumn{2}{|c|}{ Gender } & \multicolumn{2}{|c|}{$\begin{array}{l}\text { Major (The data only came } \\
\text { from the students at Beijing } \\
\text { Normal University) }\end{array}$} & \multirow[t]{2}{*}{$\begin{array}{c}\text { Risk } \\
\text { Preference }\end{array}$} \\
\hline & Male & Female & Natural Science & $\begin{array}{c}\text { Social } \\
\text { Science }\end{array}$ & \\
\hline Mean & 588.73 & 676.37 & 551.22 & 580.67 & $49.3 \%$ \\
\hline $\begin{array}{l}\text { Standard } \\
\text { Deviation }\end{array}$ & 375.58 & 357.34 & 395.198 & 411.974 & 0.2396 \\
\hline Midian & 750 & 800 & 750 & 800 & $50 \%$ \\
\hline $\mathrm{K}-\mathrm{W}$ & \multicolumn{2}{|c|}{0.031} & \multicolumn{2}{|c|}{0.507} & 0.016 \\
\hline
\end{tabular}

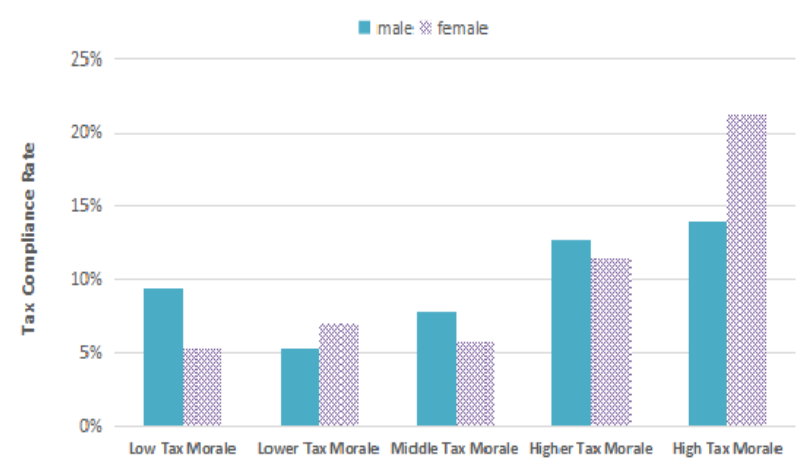

FIGURE IV. THE PERCENTAGES OF DIFFERENT GENDER IN THE DIFFERENT TAX MORALE GROUPS
From the Table 6, we could get that the median of different participants' risk preference is $50 \%$, and the mean is $49.3 \%$. In addition, the risk-lovers for $27.9 \%$ of the participants, $36.9 \%$ are the risk neutral person, $35.2 \%$ are the risk-averters. It proved that only a small number of participants were risklovers. After the normal test ( $\operatorname{sig}=0.000$ ), it was concluded that the risk preference of the participants was not normal distribution. The significance of $\mathrm{k}-\mathrm{w}$ in non-parametric test found that, the risk preference of participants was significantly correlated with the tax morale of participants themselves $(\mathrm{P}=0.016, \mathrm{P}<0.05)$. After the significantly tested $(\mathrm{P}=0.031$, $\mathrm{P}<0.05$ ), we got that there is also a significant correlation between gender and tax morale. However, the significance test of major and tax morale is $\mathrm{P}=0.507(\mathrm{P}<0.05)$, so we cannot reject the original hypothesis. From the figure 4, we can see that in the low tax morale group, the percentage of male participants was significantly higher than that of women, while the percentage of female participants in the high tax morale group was significantly higher than that of men. Finally, we indicate that there is no significant correlation between the professional difference of the participants and the distribution of tax morale.

\section{CONCLUSIONS}

Through the analysis of experimental results, we can get the following conclusions:

1) The distribution of taxpayers' initial declared income is not a normal distribution, because the taxpayer is not only influenced by the tax morality, but also has the common role of other personal factors such as risk preference. In addition to being influenced by their own tax morale, the taxpayer also has an influence of risk preference and other personal factors.

2) On the premise that the initial conditions of taxpayers are the same, although there are different tax mechanisms, there is no significant difference in the distribution of taxpayers' tax morale. However, there is a significant difference in the distribution of tax morale between different people. So, whether it's in future research, or when the government sets tax policy, it's important to consider the differences between different regions and different populations.

3) The risk preference and gender of different taxpayers were correlated with their tax morale. As the psychological factor of taxpayers, tax morale has obvious correlation with the taxpayer's own preference for risk. In addition, as with other scholars, the tax compliance rate of male taxpayers is significantly lower than that of female taxpayers. What's more, from the results of the experiment, female taxpayers' tax morale is significantly higher than that of male taxpayers.

Finally, the result proves that we turned the declared income of taxpayers into their own tax morale differences has great practical significance. To sum up, the distribution of tax morale reflects the real motive of tax evasion at the beginning of tax payment. There is no significant difference in the distribution of taxpayers in different tax regimes. However, we can conclude that both the risk preference of taxpayers and the gender difference have a significant correlation with taxpayers' tax morale. Therefore, when the government sets tax policy, it is necessary to consider the behavior of different tax morale 
people and taxpayers with different genders and different risk preferences, in order to improve the overall taxpayers' compliance rate.

\section{ACKNOWLEDGMENT}

We dare not say that the methods mentioned in this paper are more accurate than those of subjective measures, which compared with the quantitative data of taxpayers' tax morale in WVS. But in the future, if we can work together with the fields of brain cognition and neuroscience, to further explore the distribution of tax morale among taxpayers and its relationship with tax compliance, we believe that there will be more reliable, even unexpected breakthroughs.

\section{REFERENCES}

[1] Alm J. Tax Compliance and Administration[J]. Public Administration \& Public Policy, 1999.

[2] Benno Torgler. To evade taxes or not to evade: that is the question[J]. Journal of Socio-Economics, 2003(32):283-302.

[3] Nigar Hashimzade, Gareth D. Myles, Binh Tran-Nam. New Approaches to the Economics of Tax Evasion[J]. Working Paper, 2010.

[4] Mccaleb T S. Tax Evasion and the Differential Taxation of Labor and Capital Income[J]. Public finance $=$ Finances publiques, 1976, 31(2):287-294.

[5] Grable J E. Financial Risk Tolerance and Additional Factors That Affect Risk Taking in Everyday Money Matters[J]. Journal of Business \& Psychology, 2000, 14(4):625-630.

[6] Nelson J A. Are Women Really More Risk-Averse than Men?[J]. Social Science Electronic Publishing, 2012.

[7] Bönte W. Gender differences in competitive preferences: new crosscountry empirical evidence[J]. Applied Economics Letters, 2015, 22(1):71-75.

[8] Roth J.A, Scholz J.T. Witte A.D. Taxpayer Compliance, Volume 1: An Agenda for Research[M]. Philadelphia: University of Pennsylvania Press,2005, 39-46.

[9] Frey B S, Torgler B. Tax morale and conditional cooperation[J]. Journal of Comparative Economics, 2007, 35(1):136-159.

[10] Brizi A, Giacomantonio M, Schumpe B M, et al. Intention to pay taxes or to avoid them: The impact of social value orientation[J]. Journal of Economic Psychology, 2015, 50(3):22-31.

[11] Grundmann S, Lambsdorff J G. How income and tax rates provoke cheating - An experimental investigation of tax morale[J]. Journal of Economic Psychology, 2017, 63:27-42.

[12] Huang Y, Wu J, Zhou Y, et al. Strategy Preference Distribution in the Weakest-Link Game: An Analysis Based on Lab Experiments[J]. Open Journal of Social Sciences, 2016, 04(5):9-14.

[13] Casal S, Kogler C, Mittone L, et al. Tax compliance depends on voice of taxpayers[J]. Journal of Economic Psychology, 2016, 56:141-150.

[14] Torgler B. Tax morale : theory and empirical analysis of tax compliance[J]. Torgler Benno, 2003.

[15] Alm J, Mckee M. Tax compliance as a coordination game $\mathfrak{\xi}[\mathrm{J}]$. Journal of Economic Behavior \& Organization, 2004, 54(3):297-312.

[16] Cummings R G, Martinez-Vazquez J, Mckee M, et al. Effects of Tax Morale on Tax Compliance: Experimental and Survey Evidence[J]. Ncer Working Paper, 2006.

[17] Torgler B. Speaking to Theorists and Searching for Facts: Tax Morale and Tax Compliance in Experiments[J]. Journal of Economic Surveys, 2010, 16(5):657-683.

[18] Halla M. Tax Morale and Compliance Behavior: First Evidence on a Causal Link[J]. B.e.journal of Economic Analysis \& Policy, 2012, 12(1):285-298.

[19] Alm J, Mcclellan C. Tax Morale and Tax Compliance from the Firm's Perspective[J]. Kyklos, 2012, 65(1):1-17.
[20] Riahi-Belkaoui A. Relationship between tax compliance internationally and selected determinants of tax morale[J]. Journal of International Accounting Auditing \& Taxation, 2004, 13(2):135-143. 